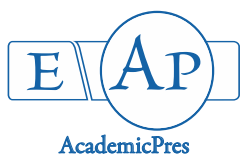

Uniyal P et al. (2021)

Notulae Scientia Biologicae

Volume 13, Issue 3, Article number 10915

DOI: $10.15835 /$ nsb13310915

Research Article

\title{
Leaf venation patterns in Saxifraga L. species (Saxifragaceae) of Indian Western Himalaya and its taxonomic implications
}

\author{
Priyanka UNIYAL ${ }^{1 *}$, Dharmendra SINGH RAWAT ${ }^{2}$, \\ Satish CHANDRA ${ }^{3}$ \\ ${ }^{1}$ H.N.B. Garhwal University, Department of Botany, SRT campus, Tehri Garhwal 249199, Uttarakhand, \\ India; pilu.uni.octa@gmail.com (*corresponding author) \\ ${ }^{2}$ G.B. Pant University of Agriculture \& Technology, Department of Biological Sciences, C.B.S.H., Pantnagar 263145, Uttarakhand, \\ India;drds_rawat@yahoo.com \\ ${ }^{3}$ Government Degree College Tiuni, Department of Botany, Dehradun-248199, Uttarakhand, \\ India; satishchandrasemwal@gmail.com
}

\begin{abstract}
Leaf venation is an important trait used for specifying and grouping plants. In the present study leaf venation types of 30 Saxifraga L. species, found in Indian Western Himalaya, were studied. Out of these, leaf venation patterns of 20 species were not previously studied. In total, five major types of leaf venations viz. acrodomous (perfect-basal; perfect-suprabasal; imperfect-suprabasal), camptodromous (eucamptodromous), campylodromous, hyphodromous, and palinactinodromous - were recorded. Section Micranthes showed palinactinodromous; section Ciliatae showed mainly acrodromous; section Mesogyne showed palinactinodromous; and sect. Porphyrion showed acrodromous, eucamptodromous and hyphodromous types of venations. Palinactinodromous venation type was found to be the ancestral type. Further molecular study is needed to be done to solve the taxonomic complexity of the genus.
\end{abstract}

Keywords: leaf venation; Micranthes; Saxifraga; Saxifragaceae; Western Himalaya; Uttarakhand

\section{Introduction}

Leaf venation refers to the pattern of veins and vein branching in a leaf (Simpson, 2019). Foliar veins and veinlets help to conduct water, minerals, hormones and food between the leaf and the stem, and within the leaf. They also provide mechanical support to the leaf. Different variations in leaf vein patterns in different plant species have been used in plant identification in palaeobotany. In the flowering plants two traditional categories (dicotyledons and monocotyledons) can simply be differentiated on the basis of leaf venation baring few exceptions. It is thus an important trait of plants used in specifying and grouping plants (Walls, 2011). Patterns of veins can be used as fingerprints to characterize plant taxa (Corner, 1964). The most widely used and comprehensive classification of leaf venation was given by Hickey $(1973,1979)$. The Hickey's classification was developed further in the manual of leaf architecture (Ellis et al., 2009).

Saxifraga L. (sensu lato), the largest genus in the family Saxifragaceae, is found mostly in the cold rocky terrains of Europe, North America and Sino-Himalayan region. The genus has around 495-543 species in the

Received: 24 Feb 2021. Received in revised form: 06 Aug 2021. Accepted: 11 Aug 2021. Published online: 18 Aug 2021.

From Volume 13, Issue 1, 2021, Notulae Scientia Biologicae journal uses article numbers in place of the traditional method of continuous pagination through the volume. The journal will continue to appear quarterly, as before, with four annual numbers. 
world (Akiyama and Gornall, 2012; The Plant List, 2013; POWO, 2017). The Sino-Himalayan region is one of the diversity centres for this genus and the Indian Himalayan region adjacent to China sustains 64 species, 4 subspecies and 5 varieties of Saxifraga (Agnihotri and Husain, 2013) while Nepal Himalaya has 91 species (Akiyama and Gornall, 2012), and Bhutan has about 75 species (Grierson, 1987). In India, about 61 species of Saxifraga are known in Western Himalaya (Uniyal, 2016, unpublished) and the members of this genus are found growing in altitudinal range of 1500-6000 $\mathrm{m}$ above sea level.

The earliest reference of leaf venation study is of Galloe (1910) who provided an account of 10 arctic Saxifraga species. Engler and Irmscher $(1916,1919)$ in their monograph on Saxifraga have also drawn leaf venation in some species. Fuller and Hickey (2005) studied venation of 2 species of Saxifraga as out group while making their studies in Gunneraceae. Zhang et al. (2015) have reported leaf venation patterns in 150 species of Saxifraga including many Sino-Himalayan species and representing 13 sections of the genus. Three main types of venation patterns in the genus were reported as - acrodomous, camptodromous and palinactinodromous.

In the present study, 30 species of Saxifraga L., collected from subalpine and alpine regions of Uttarakhand and available in G.B. Pant University herbarium, Pantnagar, India, were studied for the type of leaf venation pattern present in them.

\section{Materials and Methods}

The study area of the present work is the land area covered by the Western Indian Himalaya comprising of three states - Jammu \& Kashmir, Himalchal Pradesh and Uttarakhand, extending at latitudinal range of $28^{\circ} 43^{\prime} \mathrm{N}-37^{\circ} 05^{\prime} \mathrm{N}$ and at longitudinal range of $72^{\circ} 02^{\prime} \mathrm{E}-81^{\circ} 02^{\prime} \mathrm{E}$ (Sidhu and Surya, 2014). Samples of species were collected by D.S. Rawat over the years from different localities of Western Himalaya. The present research was carried out for the duration of one year. Leaves from the 30 species (including 5 unidentified species) of genus Saxifraga available in G.B. Pant University Herbarium were collected. Leaf venation of the specimens were drawn and studied by modifying the method given by Payne (1969). Leaves from different species were submerged in $10 \% \mathrm{KOH}$ solution in separate petri-dishes at room temperature for 3-10 days (depending upon the thickness/ texture of the leaves) till they became translucent. Then the translucent leaves are washed with tap water 2-3 times and placed in 50\% commercial bleach solution for 10-20 minutes. The leaves are again washed with tap water 2-3 times and mounted in glycerine on separate glass slides and covered with cover slips. The leaves are then observed under a dissecting microscope (MSW-108DM, 10x). The venation pattern is identified using the classification of leaf architecture described by Hickey $(1973,1979)$.

\section{Results and Discussion}

Patterns of veins can be used as fingerprints to characterize plant taxa (Corner, 1964). The most widely used and comprehensive classification of leaf venation was produced by Hickey $(1973,1979)$. He based his classification on the pattern of distribution of primary veins in a leaf. He gave 6 major types of leaf venation

subdividing further into different sub-types. In this study five major types and four sub types of leaf patterns were found. These leaf venation types are:

1. Acrodromous (perfect-basal, perfect-suprabasal, imperfect-basal)

2. Palinactinodromous

3. Campylodromous

4. Camptodromous (Eucamptodromous)

5. Hyphodromous 
The types of venations in studied 30 species are listed in Table 1 and compared with the earlier report by Zhang et al. (2015). The illustrations of the types of leaf venation patterns are drawn in Figure 1.

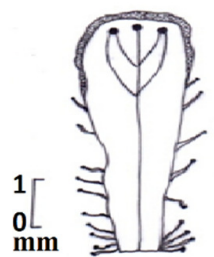

S. andersonii

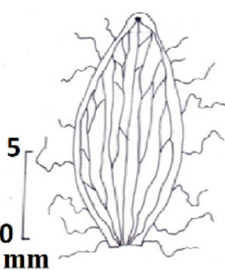

S. hirculoides

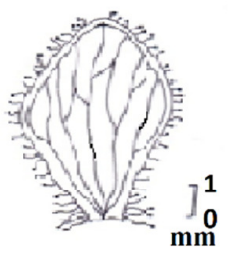

S. lychnitis

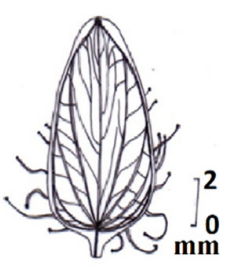

S. parnassifolia

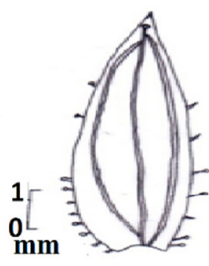

S. wallichiana

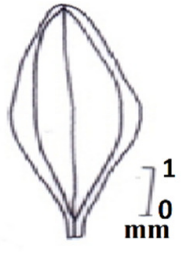

S. aristulata

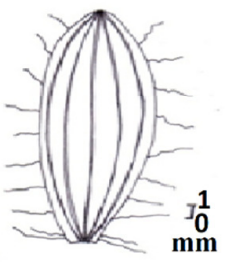

S. hirculus

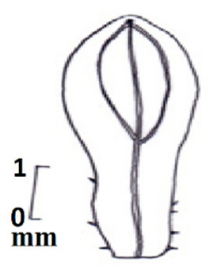

S. microphylla

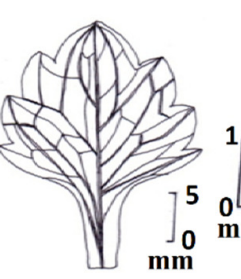

S. pseudopallida

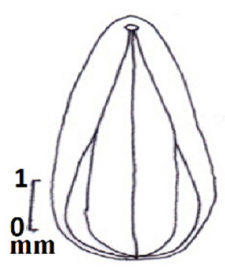

Saxifraga sp. A

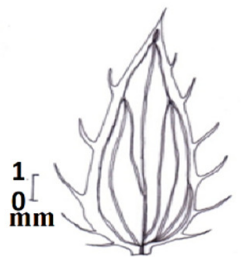

S. brachypoda

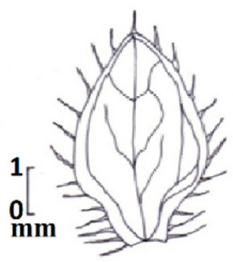

S. hispidula

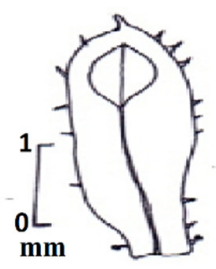

S. jacquemontiana S. kumaunensis

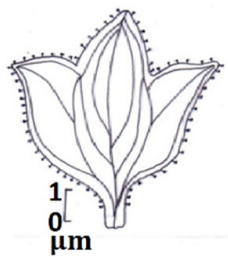

S. cernua

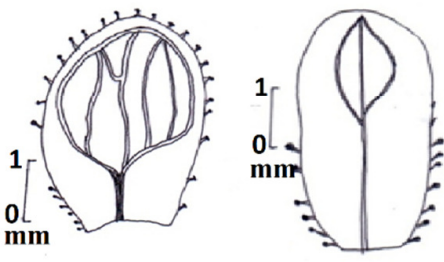

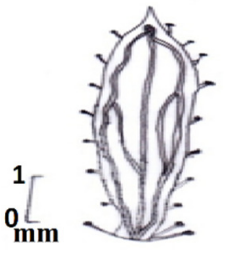

S. filicaulis

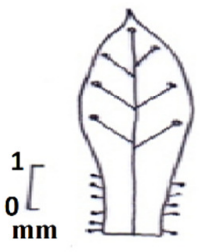

S. lilacina

S. minutissima S. moorcroftiana $S$. mucronulata
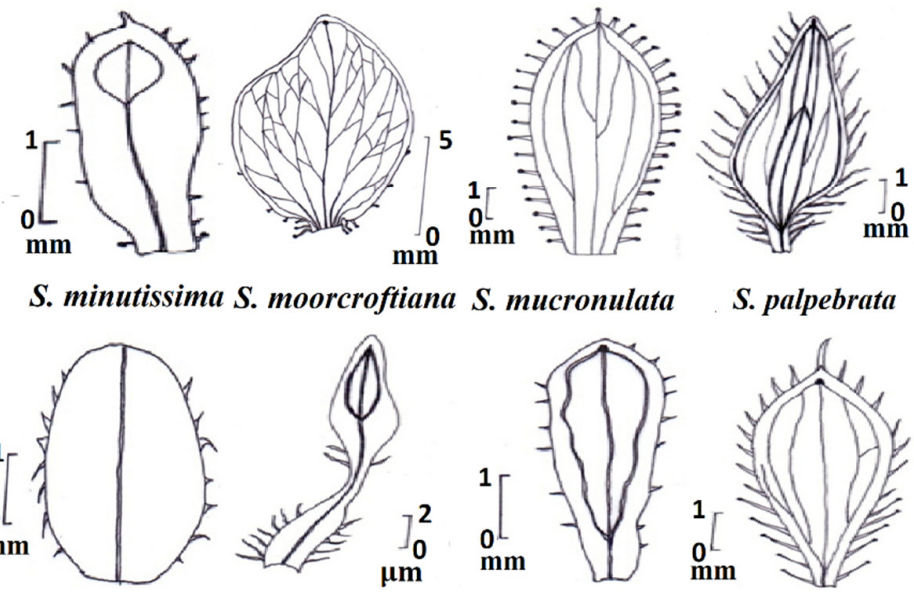

S. palpebrata

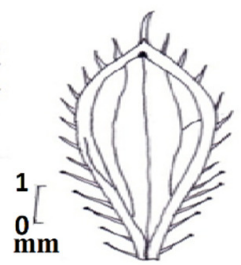

S. pulvinaria

S. saginoides

S. stella-aurea

S. stenophylla
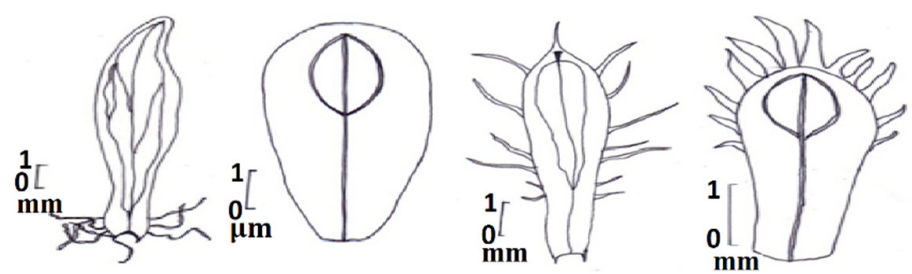

Saxifraga sp. B

Saxifraga sp. C Saxifraga sp. D

Saxifraga sp. E

Figure 1. Venation patterns in studies species of Saxifraga

Section wise listing of the species shows that four sections (Porphyrion, Mesogyne, Ciliatae, Micranthes) are represented by studied species. Micranthes section of Saxifraga (sensu lato) is considered as a separate genus currently which is basal to Saxifraga (sensu stricto) in the phylogenetic tree (Tkach et al., 2015; Gao et al., 2015) as shown in Figure 2. One species of this section S. pseudopallida (now Micranthes melanocentra was studied in the present work and palinactinodromous venation was recorded in it. This section is known to have palinactinodromous venation as reported by Zhang et al. (2015). 
Another section Mesogyne is represented by $S$. cernua L. in present study. In this species young leaves showed acrodromous (perfect-basal) type of venation but the mature leaves showed palinactinodromous venation. This species and other species of this section are reported to have palinactinodromous venation (Zhang et al., 2015).

In this study, section Porphyrion is represented by five species - S. andersonii, S. kumaunensis, S. lilacina, S. pulvinaria and an unidentified species mentioned as Saxifraga species 'C'. This unidentified species have characteristic lime secreting glands based on which it is placed here. This section has three different types of venation. $S$. andersonii showed acrodromous (imperfect-suprabasal) venation while Saxifraga species 'C' and $S$. kumaunensis showed acrodromous (perfect-suprabasal) venation. Differing from these species, S. lilacina showed eucamptodromous venation and $S$. pulvinaria showed hyphodromous venation. Zhang et al. (2015) studied 15 species in this section and reported only acrodromous and camptodromous venation in this section as they have not studied S. pulvinaria which show hyphodromous venation.

Table 1. Leaf venation in species of Saxifraga L.

\begin{tabular}{|c|c|c|c|}
\hline \multicolumn{2}{|c|}{$\begin{array}{l}\text { Species and sections of Saxifraga (s.l.) } \\
\text { genus studied }\end{array}$} & Venation (present study) & Venation (Zhang et al., 2015) \\
\hline \multicolumn{4}{|c|}{ Sect. Porphyrion } \\
\hline 1. & S. andersonii Engl. & Acrodromous (Imperfect-suprabasal) & - \\
\hline 2. & S. kumaunensis Engl. & Acrodromous (Perfect-suprabasal) & - \\
\hline 3. & S. lilacina Duthie & Eucamptodromous & - \\
\hline 4. & S. pulvinaria Harry Sm. & Hyphodromous & - \\
\hline 5. & Saxifraga species C & Acrodromous (Perfect-suprabasal) & - \\
\hline \multicolumn{4}{|c|}{ Sect. Mesogyne } \\
\hline 6. & S. cernua L. & $\begin{array}{l}\text { Acrodromous (Perfect-basal), } \\
\text { Palinactinodromous }\end{array}$ & Palinactinodromous \\
\hline \multicolumn{4}{|c|}{ Sect. Ciliatae } \\
\hline 7. & S. aristulata Hook.f. \& Thomson & Acrodromous (Perfect-basal) & Acrodromous \\
\hline 8. & S. hirculoides Decne. & Acrodromous (Perfect-basal) & - \\
\hline 9. & S. hirculus $\mathrm{L}$. & Acrodromous (Perfect-basal) & Acrodromous \\
\hline 10. & S. Iychnitis Hook.f. \& Thomson & Acrodromous (Perfect-basal) & Acrodromous \\
\hline 11. & $\begin{array}{l}\text { S. moorcroftiana (Ser.) Wall. ex } \\
\text { Sternb. }\end{array}$ & Acrodromous (Perfect-basal) & - \\
\hline 12. & S. palpebrata Hook.f. \& Thomson & Acrodromous (Perfect-basal) & - \\
\hline 13. & S. parnassifolia D.Don & Campylodromous & - \\
\hline 14. & S. saginoides Hook.f. \& Thomson & Acrodromous (Perfect-suprabasal) & - \\
\hline 15. & S. brachypoda D.Don & Campylodromous & - \\
\hline 16. & S. filicaulis Wall. ex Ser. & Acrodromous (Perfect-basal) & Acrodromous \\
\hline 17. & S. hispidula D.Don & Acrodromous (Perfect-basal) & Palinactinodromous \\
\hline 18. & S. wallichiana Sternb. & Acrodromous (Perfect-basal) & Acrodromous \\
\hline 19. & S. jacquemontiana Decne. & Acrodromous (Perfect-suprabasal) & Acrodromous \\
\hline 20. & $\begin{array}{l}\text { S. microphylla Royle ex Hook.f. \& } \\
\text { Thomson }\end{array}$ & Acrodromous (Perfect-suprabasal) & - \\
\hline 21. & S. stella-aurea Hook.f. \& Thomson & Acrodromous (Perfect-suprabasal) & - \\
\hline 22. & S. minutissima D.S.Rawat & Acrodromous (Perfect-suprabasal) & Acrodromous \\
\hline 23. & S. brunoniana Wall. ex Sternb. & Acrodromous (Perfect-suprabasal) & Acrodromous \\
\hline 24. & S. mucronulata Royle & Acrodromous (Perfect-basal) & - \\
\hline 25. & S. stenophylla Royle & Acrodromous (Perfect-basal) & - \\
\hline 26. & Saxifraga species A & Campylodromous & - \\
\hline 27. & Saxifraga species B & Acrodomous (Perfect-basal) & - \\
\hline 28. & Saxifraga species D & Acrodromous (Perfect-suprabasal) & - \\
\hline 29. & Saxifraga species E & Acrodromous (Perfect-suprabasal) & - \\
\hline \multicolumn{4}{|c|}{ Sect. Micranthes } \\
\hline 30. & S. pseudopallida Engl. \& Irmsch. & Palinactinodromous & - \\
\hline
\end{tabular}


The section with largest number of species studied here is Ciliatae which is represented by 23 species. It is the largest section of Saxifraga and highly diversified in the Himalaya. Unidentified Saxifraga species 'A', 'B', ' $\mathrm{D}$ ' and ' $\mathrm{E}$ ' showed morphological characters resembling to Ciliatae hence placed here. Despite large number of species only two types- acrodromous (perfect-basal/-suprabasal) and campylodromous venation were recorded. In this study, S. parnassifolia and Saxifraga species 'A' showed campylodromous venation. Within acrodromous venation group 12 species (S. aristulata, S. hirculoides, S. hirculus, S. lychnitis, S. moorcroftiana, S. palpebrata, S. filicaulis, S. hispidula, S. wallichiana, S. mucronulata, S. stenophylla, and unidentified Saxifraga species 'B') showed perfect-basal acrodromous venation, while eight species (S. saginoides, S. jacquemontiana, S. microphylla, S. stella-aurea, S. minutissima, S. brunoniana, and unidentified Saxifraga species 'D' and 'E' showed perfect-suprabasal acrodromous venation. Zhang et al. (2015) also reported acrodromous types of venation in this section, baring $S$. substrigosa and $S$. hispidula which showed palinactinodromous venation. For the species common ( $S$. aristulata, S. hirculus, S. lychnitis, S. filicaulis, S. wallichiana, S. jacquemontiana, $S$. minutissima, $S$. brunoniana) same type of venations are recorded in present study and Zhang et al. (2015), except $S$. hispidula in which palinactinodromous venation was reported earlier but acrodromous (perfect-basal) venation was recorded here. This species (S. hispidula) is known to occur in China, Tibet, Eastern Himalaya, Bhutan, Nepal, Uttarakhand Himalaya, and morphologically variable. Specimens of Western Himalaya (Uttarakhand) have entire leaves (typical var. hispidula) while in Nepal and eastwards var. doniana with toothed leaves is more common (Grierson, 1987; Pan et al., 2001; Akiyama and Gornall, 2012). It is possible that Western Himalayan populations (S. hispidula var. hispidula, with entire leaves) may have evolved acrodromous venation considering high diversification of Ciliataesection in the Himalaya.

Zhang et al. (2015) studied evolution of venation types in Saxifraga sections by mapping this character in the phylogenetic tree proposed by Gao et al. (2015). Their study concludes that palinactinodromous venation is the putative ancestral condition which is shared by outgroups and basal sections like Irregulares and Heterisia. Our results for studied four sections (Porphyrion, Mesogyne, Ciliatae and Micranthes) and the results of Zhang et al. (2015) for rest of the sections are depicted in the current phylogenetic tree of the genus (Tkach et al., 2015) in Figure 2.

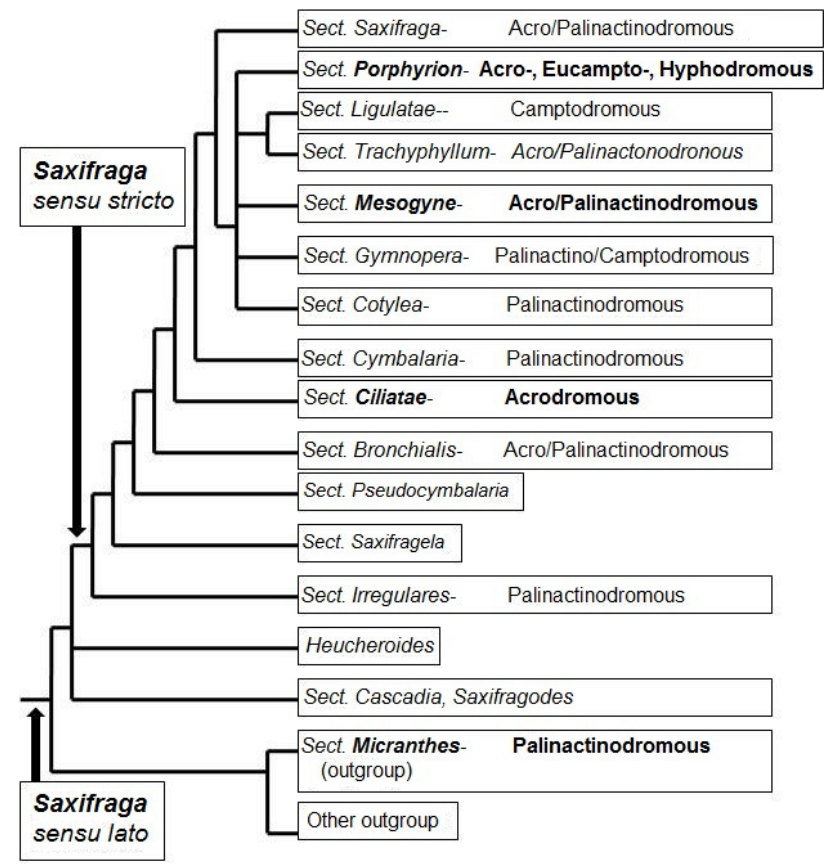

Figure 2. Phylogenetic tree of Saxifraga sections and venation patterns reported in present study (in bold face) and by Zhang et al. (2015) 
Figure 2 shows that the basal groups (Micranthes, Irregulares) and relatively advance groups (Cymbalaria, Cotylea, Mesogyne) have retained this venation. But some members of relatively advanced groups (Bronchialis, Trachyphyllum, Saxifraga) have also evolved acrodromous venation in addition to ancestral venation. This character has evolved few times and the section Ciliatae exclusively (or mainly) has evolved acrodromous venation. Section Ligulatae has evolved camptodromous venation. However, section Porphyrion has shown relatively more diversification in venation type evolving acrodromous, eucamptodromous and hyphodromous venations in the members found in the Himalaya.

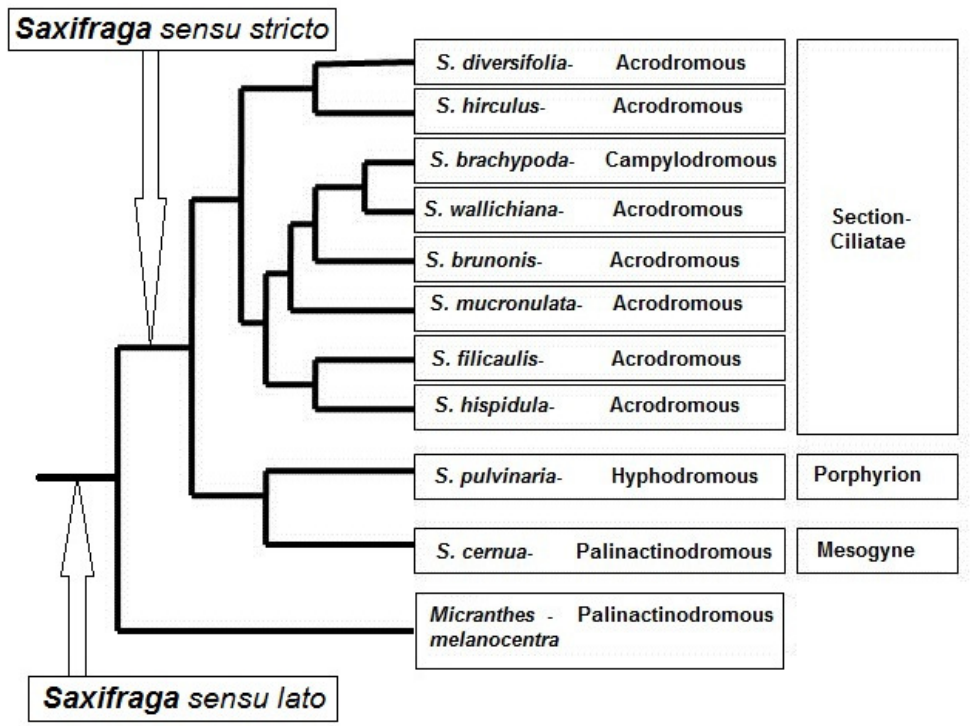

Figure 3. Venation pattern in the species common in present study and phylogenetic tree of Gao et al. (2015)

Venations of the taxa common in phylogenetic tree of Gao et al. (2015) and present study are depicted in the Figure 3. It shows palinactinodromous venation as putative ancestral character shown by Micranthes and section Mesogyne. However, S. pulvinaria of section Porphyrion, a closer group of Mesogyne, has evolved hyphodromous venation. In the Ciliatae group where majority of the species show acrodromous venation, the most advanced member $S$. brachypoda has evolved campylodromous venation.

Results of venation patterns in present study resonate with the results of Zhang et al. (2015) for the species common to both studies (S. cernua, S. aristulata, S. hirculus, S. lychnitis, S. filicaulis, S. hispidula, S. wallichiana, $S$. jacquemontiana, S. minutissima, $S$. brunoniana) except $S$. hispidula. The reason for this disagreement may be variations in leaf morphology. Our results further stabilize that Saxifraga species have similar venation in their entire range of distribution. The venation types in 20 species are being reported for the first time and, therefore, are additions to the pool of 150 species in which venation is known. However, present results also suggest more variability to only three venation types (acrodomous, camptodromous and palinactinodromous) reported earlier (Zhang et al., 2015) by adding campylodromous and hyphodromous venations.

\section{Conclusions}

Saxifraga is one of the larger genera in angiosperms and many species, particularly those occurring in the Sino-Himalayan region, are not very well known and studied. Present study adds information on venation pattern of 20 Himalayan Saxifraga species, hitherto, not known. The results resonate with earlier studies and show palinactinodromous venation as ancestral type being present in the basal group Micranthes and evolving 
in to acrodromous, camptodromous, campylodromous, hyphodromous in more evolved groups. 23 studied species of Ciliatae, the most diversified section of Saxifraga in the Himalaya, show mainly acrodromous venation baring three species ( $S$. brachypoda, $S$. parnassifolia, Saxifraga species A) which show campylodromous venation. Combined with leaf shape, venation can be useful even in the identification of herbarium specimens lacking flowering and fruiting stages. Molecular phylogenetics of Sino-Himalayan species needs to be studied in greater details to decipher evolution and diversification of genus in this important center of diversity.

\section{Authors' Contributions}

DSR: conceptualized and supervised the study, refined the original draft and have drawn figure- 2 and 3. PU: conducted the study, prepared original draft and have drawn figure-1.SC: helped in conducting the study and in writing the draft and later reviewed it. All authors read and approved the final manuscript.

\section{Acknowledgements}

This research received no specific grant from any funding agency in the public, commercial, or not-forprofit sectors.

\section{Conflict of Interests}

The authors declare that there are no conflicts of interest related to this article.

\section{References}

Agnihotri P, Husain T (2013). An overview of genus Saxifraga L. in Indian Himalayas. Annals of Plant Sciences 2(8):278283.

Akiyama S, Gornall RJ (2012). Saxifraga L. In: Watson MF, Akiyama S, Ikeda H, Pendry CA, Rajbhandari KR, Shrestha KK (Eds). Flora of Nepal. Retrieved on December 12, 2020 from http://www.floraofnepal.org/onlineflora?wildcard $=1898$

Corner EJH (1964). The life of plants. University of Chicago Press, Chicago, pp 314.

Ellis B, Daly DC, Hickey LJ, Mitchell JV, Johnson KR, Wilf P, Wing SL (2009). Manual of leaf architecture. Cornell University Press, Ithaca, New York, pp 190.

Engler A, Irmscher E (1916). Saxifragaceae-Saxifraga L. In: Engler A (Ed). Das Pflanzenreich, 67 (IV. 117. I). Verlag von Wilhelm Engelmann, Leipzig.

Engler A, Irmscher E (1919). Saxifragaceae-Saxifraga II. In: Engler A (Ed). Das Pflanzenreich, 69 (IV. 117. II). Verlag von Wilhelm Engelmann, Leipzig.

Fuller DQ, Hickey LJ (2005). Systematics and leaf architecture of the Gunneraceae. Botanical Review 7(3):295-353. https://doi.org/10.1663/0006-8101(2005)071[0295:SALAOT]2.0.CO;2

Gao QB, Li YH, Gornall RJ, Zhang ZX, Zhang FQ, Xing R, Fu PC, Wang JL, Tian ZZ, Chen SL (2015). Phylogeny and speciation in Saxifraga sect. Ciliatae (Saxifragaceae): Evidence from $p s b A-t r n H, t r n L-F$ and ITS sequences. Taxon 64(4):703-713. https://doi.org/10.12705/644.3

Galloe O (1910). The structure and biology of Arctic flowering plants. IV. Saxifragaceae. 2. The biological leaf-anatomy of the Arctic species of Saxifraga. Meddelelser om Gronland 36:237-294.

Grierson AJC (1987). Saxifragaceae. In: Grierson AJC, Long DG (Eds). Flora of Bhutan. Royal Botanic Garden, Edinburgh 1(3):485-515. 
Hickey LJ (1973). Classification of the architecture of dicotyledonous leaves. American Journal of Botany 60(1):17-33. https://doi.org/10.1002/j.1537-2197.1973.tb10192.x

Hickey LJ (1979). A revised classification of the architecture of dicotyledonous leaves. In: Metcalfe CR, Chalk L (Eds). Anatomy of the dicotyledons: Systematic anatomy of leaf and stem, with a brief history of the subject ( $2^{\text {nd }}$ edition). Clarendon Press, Oxford 1:25-39.

Pan, JT, Gornall RJ, Ohba H (2001). Saxifraga. In: Wu CY, Raven PH (Eds). Flora of China. Vol 8. Science Press, Beijing and Missouri Botanical Garden Press, St. Louis pp 280-344.

Payne WW (1969). A quick method for clearing leaves. Ward's Bulletin 8:4-5.

POWO (2017). Saxifraga L. Retrieved on December 30, 2020 from http://plantsoftheworldonline.org/taxon/urn:lsid:ipni.org:names:30002955-2

Simpson MG (2019). Plant Systematics ( $3^{\text {rd }}$ Edition). Elsevier-Academic Press, New York, USA, pp 761.

Tkach N, Roser M, Miehe G, Muellner-Riehl AN, Ebersbach J, Favre A, Hoffmann MH (2015). Molecular phylogenetics, morphology and a revised classification of the complex genus Saxifraga (Saxifragaceae). Taxon 64(6):1159-1187. https://doi.org/10.12705/646.4

The Plant List (2013). Saxifraga. Retrieved on December 24, 2020 from http://www.theplantlist.org/1.1/browse/A/Saxifragaceae/Saxifraga/

Uniyal P (2016). Studies on the genus Saxifraga L. (Saxifragaceae) in Western Himalaya, India. MSc thesis, G.B. Pant University of Agriculture \& Technology, Pantnagar, India, pp 151.

Walls RL (2011). Angiosperm leaf vein patterns are linked to leaf functions in a global-scale data set. American Journal of Botany 98(2):244-253. https://doi.org/10.3732/ajb.1000154

Zhang Z, Xia N, Gornall RJ (2015). Leaf venation patterns in the genus Saxifraga (Saxifragaceae). Phytotaxa 221(2):123136. https://doi.org/10.11646/phytotaxa.221.2.2
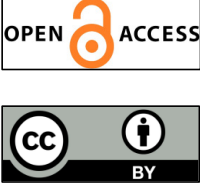

The journal offers free, immediate, and unrestricted access to peer-reviewed research and scholarly work. Users are allowed to read, download, copy, distribute, print, search, or link to the full texts of the articles, or use them for any other lawful purpose, without asking prior permission from the publisher or the author.

License - Articles published in Notulae Scientia Biologicae are Open-Access, distributed under the terms and conditions of the Creative Commons Attribution (CC BY 4.0) License.

(c) Articles by the authors; SHST, Cluj-Napoca, Romania. The journal allows the author(s) to hold the copyright/to retain publishing rights without restriction. 